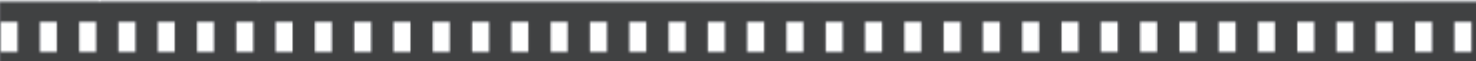

\author{
0 poder de construção de realidades pela mídia: \\ o incidente na mina San José (Chile)
}

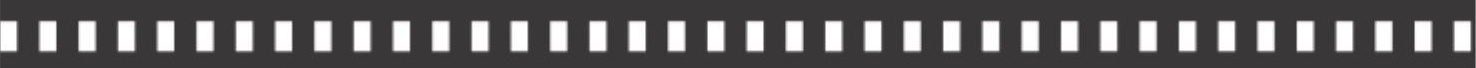

Alissar de Almeida Ayoub Ayoub

Ayoub Ayoub

Letícia Albanez de Oliveira 


\title{
0 poder de construção de realidades pela mídia: o incidente na mina San José (Chile)
}

The power of reality construction by the media: the incident at San José's coal mine (Chile)

\author{
Alissar de Almeida Ayoub Ayoub* \\ Ayoub Ayoub ** \\ LetíciaAlbanez de Oliveira $* * *$
}

\begin{abstract}
Resumo: Este trabalho aborda reflexões sobre os meios de comunicação e seu poder de induzir o olhar do público, direcionando$o$, às vezes, a uma realidade distorcida a partir da manipulação das informações presentes em textos e imagens. Considerando questões que envolvem a fotografia, como tempo, memória, afetividades, intencionalidades, é discutido o valor de uma imagem - sua criação, sua utilização e seus sentidos. Focamos a análise na capa da revista Veja, de $1^{\circ}$ de setembro de 2010, sobre o incidente na mina San José, no Chile. São utilizados autores como Perseu Abramo, Samira Chalhub, Martine Joly e Eni Orlandi para avaliar a maneira como a mídia pode utilizar elementos visuais e verbais para distorcer a realidade e influenciar pensamentos e comportamentos.
\end{abstract}

Palavras-chave: Padrões de manipulação. Distorção da realidade. Funções da linguagem. Mina San José (Chile)

\begin{abstract}
This paper reflects upon the media and its power to induce the audience's opinion, directing it, sometimes, towards a distorted reality, by manipulating information present in texts and images. Considering questions about photography, such as time, memory, affections and intentionalities, this article discusses the value of an image - its creation, application and meanings. The analysis is focused on the cover page of Veja Magazine, September 1 ${ }^{\text {st }}$ 2010, about the incident at the coal mine of San José, in Chile. Authors like Perseu Abramo, Samira Chalhub, Martine Joly and Eni Orlandi are consulted, to evaluate how the media can use visual and verbal elements to distort the reality and influence thoughts and behaviours.
\end{abstract}

Keywords: Manipulation standards. Distortion of reality. Functions of language. San José's coal mine (Chile).

\footnotetext{
* Licenciada em Artes Visuais pela Universidade Estadual de Londrina (UEL). Especialista em Fotografia pela Universidade Estadual de Londrina (UEL). E-mail: alissarayoub@gmail.com ** Jornalista. Mestre em Ciências Sociais pela Universidade Estadual de Londrina (UEL). Docente do Curso de Especialização em Fotografia: Práxis e Discurso Fotográfico da Universidade Estadual de Londrina (UEL). E-mail: ayoub@sercomtel.com.br

*** Licenciada em Artes Visuais pela Universidade Estadual de Londrina (UEL). Especialista em Fotografia pela Universidade Estadual de Londrina (UEL). E-mail: leticia.albanez@gmail.com
} 


\section{Introdução}

Considerando a importância da disseminação de conteúdos a respeito da compreensão de imagens e sua relação com o receptor, nos apoiamos em Perseu Abramo - e seus estudos sobre padrões de manipulação - e em Samira Chalhub - e suas reflexões acerca das funções da linguagem - para avaliar a maneira como a mídia utiliza elementos visuais e verbais para distorcer a realidade e tentar influenciar o pensamento e o comportamento de seu público.

Com a intenção de esclarecer alguns aspectos sobre as informações e as mensagens que recebemos da mídia, este trabalho trata, em duas abordagens, de uma análise de imagem. Discutimos a respeito das grandes empresas de comunicação, que, como detentoras da "verdade", tornamse detentoras de poder.

\section{Meios de comunicação: formação e informação}

Os meios de comunicação sempre tiveram seu papel primeiro, o de informar, bem claro perante a sociedade. As notícias - registro de fatos ocorridos - sempre foram entregues à sociedade pela imprensa e tidas como relato e esclarecimento de tais fatos, portanto, verdades. Quando a fotografia passou a fazer parte das matérias publicadas pela imprensa, a partir de 1880, ocorreu intenso crescimento na demanda de leitores e eventual aumento na concorrência dos jornais e revistas. Consideradas pela maioria como "retrato do real", as imagens passaram a acompanhar os textos e dar maior credibilidade aos fatos, reafirmando a veracidade das notícias e, por extensão, das empresas de comunicação.

Com o aumento da crença do público em relação às empresas, elas acabaram se tornando a fonte principal de informações dos acontecimentos. 
Tudo passou a ser entregue na mão do leitor, que sistematicamente espera as notícias e, acomodado, reflete cada vez menos sobre o que recebe. Assim, a grande mídia acabou se tornando uma detentora da verdade - da realidade - passando a ser não apenas um órgão de comunicação, mas um órgão de poder.

A forma como as informações são divulgadas - através da linguagem verbal ou visual - interfere em suas atribuições de sentidos e possíveis interpretações. Samira Chalhub (2002) lembra que o funcionamento das mensagens, antes de qualquer coisa, tem em vista a finalidade de transmissão, e que as linguagens estruturam-se de acordo com o fator para o qual estão inclinadas, ou seja, apresentam diversas funções, que serão aprofundadas adiante. Qualquer estratégia de comunicação - sejam as funções da linguagem, a organização de uma imagem, a escolha de palavras, e a combinação de todos os elementos é estudada e escolhida de acordo com a necessidade e a intenção de cada veículo.

As empresas de comunicação, com sua enorme capacidade de influência sobre a opinião e o comportamento da sociedade, utilizam-se disso para conduzi-la e controlá-la, muitas vezes manipulando informações e distorcendo a realidade. Dessa forma, deixam de fazer parte da esfera da sociedade civil e se inserem no campo político. Seus interesses vão além da obtenção de lucros e se direcionam ao controle do poder (ABRAMO, 2003).

\section{Imagem e texto: construção e manipulação}

Pensando nas formas de manipulação de informações pela mídia, de como ela distorce realidades, direciona os pensamentos do público e exerce influência em seu comportamento, analisamos, por dois eixos, a capa da revista Veja referente ao acidente na mina de San José, no 
Chile, ocorrido em 5 de agosto de 2010. O primeiro eixo reflete estudos de Samira Chalhub acerca das funções da linguagem e suas possibilidades de uso em uma mensagem. $\mathrm{O}$ segundo eixo toma como apoio pesquisas realizadas por Perseu Abramo a respeito de padrões de manipulações da grande imprensa. Dessa forma, analisamos imagem e texto.

A construção da imagem, desde o pensamento do fotógrafo e a escolha do tema, elementos pertencentes à linguagem fotográfica - planos, enquadramento, composição, foco, ângulos, cores - até sua posterior edição e utilização, pode, e é, utilizada de acordo com as intencionalidades de comunicação.

O recorte e a forma de 'reprodução' do cenário está diretamente atrelada à construção do significado por parte do fotógrafo. Da mesma forma que a capacidade de construção de significados, através da leitura de uma foto, está condicionada ao repertório do leitor, a leitura e um recorte de cenário a ser fotografado, ou seja, a construção mental de um significado a ser reproduzido está diretamente condicionada ao repertório do fotógrafo. (BONI, 2005, p.166).

Para se chegar à fase final da produção jornalística - a revista publicada e disponível para os leitores - há uma série de etapas, todas passando pelas mãos de editores e chefes que são responsáveis pelo conteúdo do material. A última etapa é a edição da capa. Tanto em jornais como em revistas, é nesta etapa que a linha editorial da empresa aparece com mais ênfase. Além de ser o principal motivador para a compra da revista (o marketing do produto), representa também o posicionamento ideológico de seus proprietários. É na capa que a possibilidade da intencionalidade de comunicação está mais presente.

[...] A hierarquia nas redações é dividida horizontalmente: editores e subeditores leais aos proprietários comandam, para assegurar que a cobertura não viole nem os interesses estratégicos da empresa nem as idiossincrasias e favoritismos da família proprietária. (KUCINSKI, 1998, p.27). 
Outro fator a ser considerado é que as primeiras páginas dos jornais podem ser, em muitos casos, a totalidade das informações que algumas pessoas recebem. Ayoub Ayoub (2006) destaca que, no Brasil, o preço de jornais e revistas é considerado caro para os padrões da população. Por isso, capas de jornais e revistas acabam sendo lidas em expositores nos locais de venda. Isso demonstra que, para as empresas, é preciso destacar as capas com mensagens de conteúdo ideológico definido.

As revistas semanais possuem características especiais quando comparadas aos demais veículos de comunicação. Além de repercutirem os anseios da classe média, são consideradas verdadeiras usinas ideológicas dos conceitos e preconceitos desse segmento da população. Bernardo Kucinski (1998) afirma que as revistas são lidas por um público considerável e acabam reaproveitadas em consultórios de médicos ou dentistas, além de bibliotecas de escolas (onde são utilizadas em trabalhos escolares). Esses fatos reforçam o conceito de intencionalidade de comunicação.

A elaboração de um texto - a escolha das palavras, do assunto, do código a ser utilizado e do canal pelo qual a mensagem vai transitar - é dada por etapas, e também parte das ideias do autor, assim como as imagens. Todas essas etapas de construção atuam como filtros capazes de alterar as informações contidas na imagem e no texto, sejam intencionalmente ou não.

Adotando como fatores que sustentam o modelo de comunicação, tais como emissor, receptor, canal, código, referente e mensagem, Samira Chalhub (2002) reforça a classificação de Roman Jakobson a respeito das funções da linguagem, dividindo-as em seis: função referencial, função emotiva, função conativa, função fática, função poética, e função metalinguística. Chalhub ressalta, ainda, a possibilidade de haver várias funções numa mensagem, contudo, sempre uma delas prevalecerá.

De acordo com Perseu Abramo (2003), as manipulações por parte da grande imprensa podem ser classificadas em cinco padrões: padrão de ocultação, padrão de fragmentação, padrão de inversão, padrão de indução, e padrão global ou padrão específico de jornalismo de televisão e rádio. 


\section{Acidente na mina San José: contextualização}

No dia 5 de agosto de 2010, no deserto do Atacama, a $800 \mathrm{~km}$ de Santiago, Chile, um desmoronamento interrompeu a única saída da mina San José, de onde são extraídos ouro e cobre. Um grupo de trabalhadores que estava acima do ponto do deslizamento conseguiu sair, mas outros trinta e três operários ficaram presos sob o bloqueio de rochas.

Na reportagem da revista Veja o engenheiro Sérgio Médice de Eston, do departamento de minas e petróleo da Universidade de São Paulo, afirma que toda mina deve ter um acesso alternativo, para saída em caso de acidentes, e a mina San José não possuia. A mina, explorada há mais de cento e vinte anos, tem mais de oitenta acidentes registrados. Sua última interdição foi em 2007, por falta de condições de segurança, porém, em 2008 ela foi aberta pelo órgão do governo chileno responsável pela fiscalização. Na matéria da Veja, é afirmado que "segundo a imprensa chilena, o responsável por assinar a liberação da mina admite que o fez sem ter conhecimento dos problemas que ela apresenta".

Por quase três semanas não foi possível saber se os operários estavam vivos. Após dezoito dias de tentativa de contato, foi possível receber, por meio de sondas, informações e imagens sobre a situação dos trabalhadores soterrados. A 700 metros de profundidade, os mineiros se mantinham em condições precárias de alimentação, saúde física e psicológica. Essas imagens foram utilizadas para acompanhamento e avaliações do local e dos trabalhadores.

A capa da revista (Figura 1) traz um recorte de uma dessas imagens, feita no dia 26 de agosto. Nele destaca-se, em baixa qualidade, o rosto de um dos trabalhadores que ficou preso, em tons escuros e que não mostrava detalhes sobre o local. A chamada de capa diz em letras grandes "OS HOMENS DO ABISMO" e traz algumas informações: "Presos em 
um bolsão de rocha a 700 metros de profundidade, 33 mineiros de cobre e ouro vão ser mantidos vivos por quatro meses na mais longa e documentada experiência humana de isolamento coletivo subterrâneo."

Em agosto, na época do acidente, o clima no Brasil era de propaganda eleitoral. Os três candidatos na disputa da Presidência da República que lideravam as pesquisas de intenção de voto eram Dilma Rousseff, do Partido dos Trabalhadores (PT), José Serra, do Partido da Social Democracia Brasileira (PSDB), e Marina Silva, do Partido Verde (PV), que com frequência apareciam na mídia.

Nos últimos tempos a grande disputa política pelo poder presidencial no Brasil se concentrava, basicamente, entre os candidatos do PT e do PSDB, que ocupavam notável espaço nas matérias realizadas pela imprensa. Grande parte desse material acaba evidenciando o posicionamento partidário das empresas de comunicação, mesmo quando afirmam imparcialidade.

\section{Representação e interpretação}

A imagem cumpre sempre uma função informativa. Seja uma fotografia, um desenho, um filme, uma escultura, há sempre a transmissão de alguma informação, de acordo com diversos elementos próprios de cada linguagem.

Quando nos defrontamos com essas imagens, a tendência é recriá-las por meio de conteúdos paralelos. Lúcia Santaella (1984, p.70) afirma que somos seres de linguagem, seres simbólicos, dessa forma, "compreender, interpretar é traduzir um pensamento em outro pensamento num movimento ininterrupto, pois só podemos pensar um pensamento em outro pensamento".

No momento em que ativamos nossos pensamentos, fazemos associações de uma imagem com outra, de um conteúdo com outro, utilizando referências de experiências anteriores. É o que Charles S. 
Peirce chama de "terceiridade" em seus estudos a respeito da semiótica. De acordo com Santaella, sobre Peirce, nós só conhecemos o mundo porque o representamos e o interpretamos. E criamos signos, que são pontes entre nós, nossos pensamentos e os fenômenos. Assim, estamos situados na fronteira entre a consciência e a percepção. Na relação de "Terceiridade" temos o signo como um primeiro, o objeto como um segundo e o interpretante - que seria a relação de interpretação - como um terceiro.

[...] o simples ato de olhar já está carregado de interpretação, visto que é sempre o resultado de uma elaboração cognitiva, fruto de uma mediação sígnica que possibilita nossa orientação no espaço por um reconhecimento e assentimento diante das coisas que só o signo permite. (SANTAELLA, 1984, p.68).

Muitos signos já impregnados de sentidos na memória coletiva e em nosso repertório imagético funcionam como dispositivos que nos levam diretamente a um assunto quando aparecem em qualquer contexto. A publicidade trabalha, e muito bem, com esses aspectos do nosso inconsciente em anúncios e propagandas. Mas a mídia, no geral, também pode se apropriar dessa estratégia, utilizando esse e outros elementos capazes de seduzir e convencer o público.

\section{Análise da capa}

Para a análise da imagem da capa escolhida (Figura 1), é preciso levar em consideração o contexto político no qual o Brasil se encontrava na época do acidente da mina: o período eleitoral. Adotamos como referencial as pesquisas de Perseu Abramo (2003) e de Samira Chalhub (2002) e, ainda, percepções e possíveis interpretações na relação entre imagens escolhidas para capas da revista, pensando no caráter sígnico e no contexto linguístico. 
Figura 1 - Capa da revista Veja, ano 43, n. 35, de $1^{\circ}$ de setembro de 2010

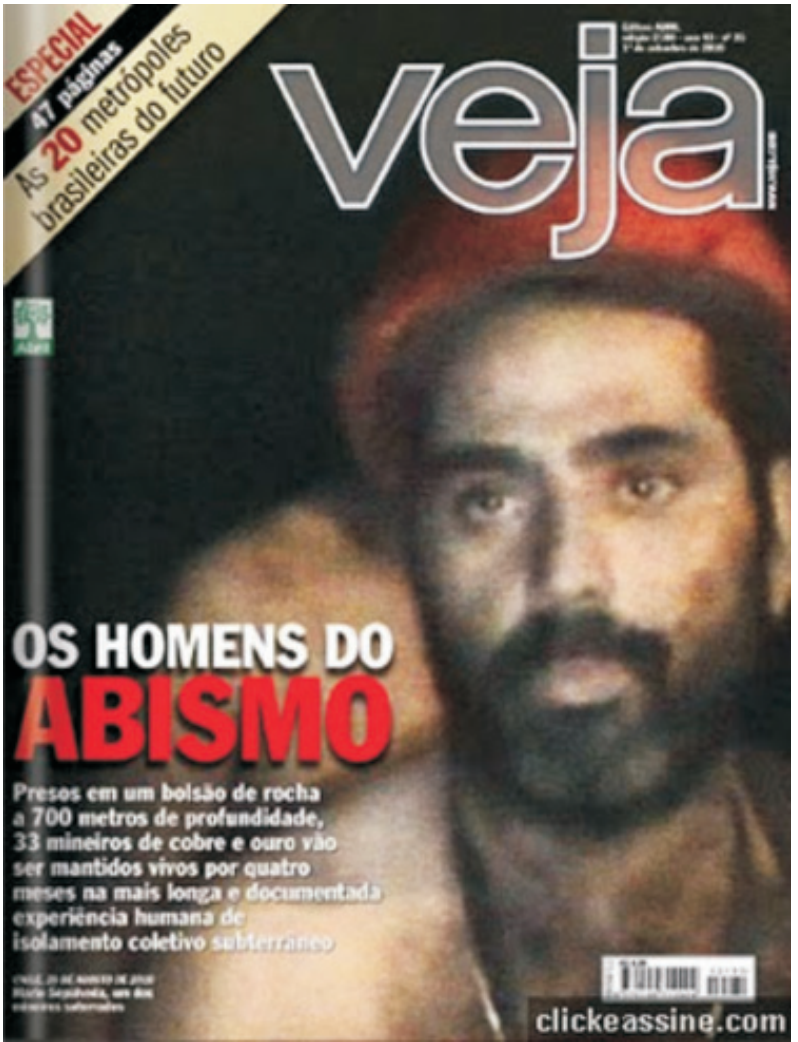

Fotografia: Frame de gravação videográfica Fonte: Veja, ano 43, n.35, set. 2010 - Capa

A Veja, como revista de maior circulação no Brasil, portanto, grande formadora de opinião, ao tratar o acidente da mina San José como reportagem principal, apresenta na capa uma imagem que se assemelha a tantas outras já publicadas. Levantamos hipóteses de relações entre essa imagem e a maneira "padronizada" por vários aspectos - como cor, composição e os "personagens" - sígnicos que a revista costuma apresentar para os assuntos e imagens relacionados aos "partidários de esquerda", ao Partido dos Trabalhadores (PT), ao presidente Lula e ao Movimento dos Trabalhadores Rurais Sem Terra (MST), por exemplo. 


\section{Formas do silêncio: percepção, recepção e estética}

Eni Orlandi (1997) traz a noção de silêncio e a distingue do implícito, que faz referência ao dito; já o silêncio significa por si, possui uma relação constitutiva com a significação. Para a autora, o silêncio constitutivo é um "mecanismo que põe em funcionamento o conjunto do que é preciso não dizer para poder dizer". (ORLANDI, 1997, p.76).

Da mesma forma que encontramos os sentidos do silêncio na linguagem verbal, encontramos na linguagem fotográfica que, por sua vez, afirma o real e tudo que existe, mas cria ficção. É uma linguagem indiciária, não icônica como os códigos de representação nos fazem crer, e se sustenta como vestígio do real; é objeto de criação de alguém.

Os vestígios de realidade circulam pela área da subjetividade - essência da sensibilidade. Ao criar essas imagens, inúmeras questões são levantadas, escolhas são feitas. Encontramos em Martine Joly (2006) maneiras de ler as imagens e entender a relação intrínseca entre criação e recepção - função estética. Cria-se uma relação entre o fator estético de uma imagem e sua significação. No caso da capa analisada, a significação encontra-se atrelada ao silêncio. Talvez fora de seu contexto a imagem torne-se um pouco vazia. Não é possível concluir nada concreto, refletimos e supomos inúmeras coisas. As informações, por se tratar de uma imagem jornalística, são poucas. A baixa qualidade da imagem é compreendida ao constar no texto que são feitas por sondas, mas se essa informação não fosse dada deixaria mais dúvidas.

Para uma análise é sempre importante levar em conta a função cumprida pela imagem. Joly (2006) nos permite relacionar diretamente a função de conhecimento com a função estética da imagem. Portanto as imagens, mais do que as palavras, causam no espectador uma expectativa específica. Fotografar e analisar uma fotografia são duas maneiras de desvendar o mundo ou o ambiente. Desvendar é conhecer e conhecer é perceber. E a percepção é a revelação do mundo. 
A estética é que cria o discurso de uma imagem, e não seu conteúdo. A estética conduz. Voltamos à imagem e seu silêncio: devemos pensar sua significação a partir do discurso e não do produto.

[...] é difícil classificar certas imagens. É o caso das fotografias de imprensa: supostamente, deveriam ter uma função referencial, cognitiva, mas na realidade, situam-se entre a função referencial e a função expressiva ou emotiva. Uma foto de reportagem testemunha bem uma certa realidade, mas também revela a personalidade, as escolhas, a sensibilidade do fotógrafo que a assina. (JOLY, 2006, p.58).

A imagem, linguagem específica e heterogênea, possui ferramentas. Jogar com a ausência e a presença é dar sentidos diversos à imagem, trabalhar relações. E a mensagem visual possui significação tanto nas presenças como nas ausências, e aí ocorre a participação das lembranças, que, conscientemente ou não, entram em ação e fazem associações com outros elementos. (JOLY, 2006).

[...] não há discurso que não se relacione com outros. Em outras palavras, os sentidos resultam de relações: um discurso aponta para outros que o sustentam, assim como para dizeres futuros. [...] Um dizer tem relação com outros dizeres realizados, imaginados ou possíveis. (ORLANDI, 1997, p.39).

\section{Funções da linguagem}

A capa (Figura 1) mostra o recorte da imagem de um homem aparentemente sujo e sem camisa, com barba vasta e usando um capacete vermelho de operário. Frequentemente, a cor vermelha está presente quando se trata de assuntos da "esquerda", pois simbolicamente a representa (exemplo: a estrela vermelha do PT, as bandeiras do MST e dos partidos comunistas). A cor sempre tem maior destaque na composição de uma imagem, independente do assunto tratado. A revista Veja além de 
utilizar a cor nesse sentido de representação e destaque, abusa dessa estratégia de manipulação, quando, com a união de outros elementos, constrói imagens que remetam à violência, lutas e guerras. Nessa cor, também, há a palavra "abismo" na frase "os homens do abismo", que ganha grande destaque em meio às demais cores neutras da capa. $\mathrm{O}$ olhar do personagem leva o olhar do espectador para longe, sua expressão é um tanto neutra, sua proximidade com a palavra abismo e a sujeira em seu rosto levam a relações negativas.

Figura 2 - Interior da revista; apresentação e inicio da matéria sobre o incidente

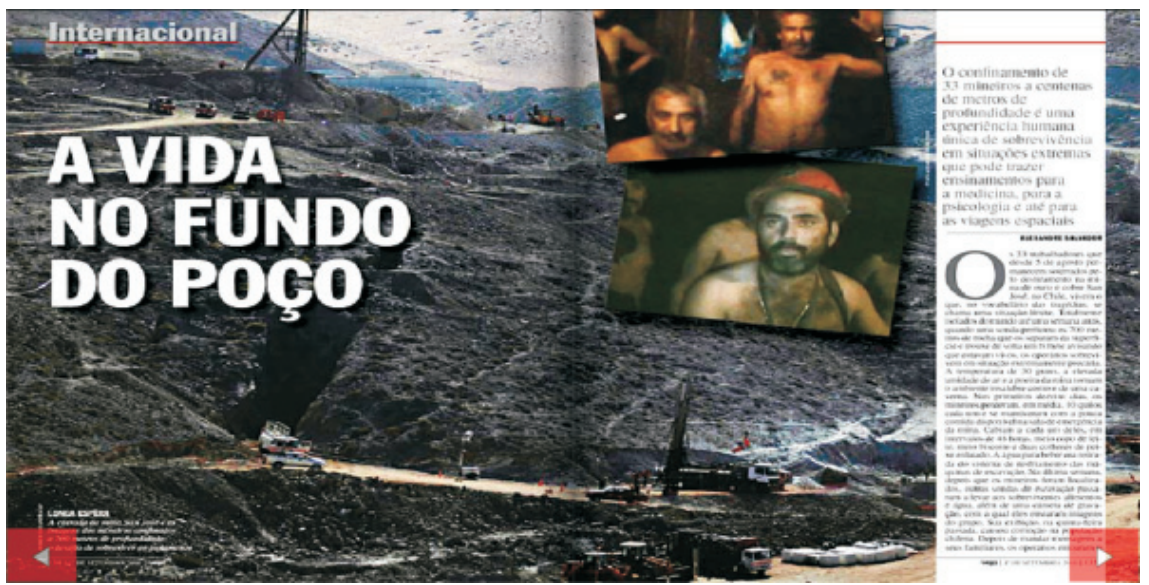

Fotografia: Frame de gravação videográfica

Fonte: Salvador (2010, p.135)

Pensando nas possibilidades de interpretação da frase destacada na capa, é necessário refletir acerca da intencionalidade do emissor (o autor) direcionada ao receptor (o leitor), que receberá a mensagem (a imagem e a frase). Esses fatores dizem respeito às funções de linguagem, estudadas por Chalhub (2002, p.8):

Numa mesma mensagem [...] várias funções podem ocorrer, uma vez que, atualizando concretamente possibilidades de uso do código, entrecruzam-se diferentes níveis de linguagem. A emissão, que organiza os sinais físicos em forma de mensagem, colocará ênfase em uma das funções - e as demais dialogarão em subsídio. 
Tendo em vista que todo texto apresenta diversas formas de leitura, as funções da linguagem determinam o fator, ou fatores, mais importantes na construção de uma informação. Enfatizar algum recurso fica a cargo da capacidade criativa do autor, ou emissor, da mensagem. O repertório, tanto de quem cria a mensagem, como de quem vai recebê-la, é extremamente valioso - quanto mais vasto, mais aprimorada é a comunicação.

O texto da capa diz: "Os homens do abismo". Em seguida: "Presos em um bolsão de rocha a 700 metros de profundidade, 33 mineiros de cobre e ouro vão ser mantidos vivos por quatro meses na mais longa e documentada experiência humana de isolamento coletivo subterrâneo". Dentre as diversas funções, detectamos a chamada função referencial, predominante na capa. Sendo uma das mais comuns, nela o referente predomina na mensagem. Trata-se de uma comunicação direta, objetiva, muito usada nos jornais, revistas e textos científicos, onde se pretende passar a mensagem de maneira clara e legível.

Há também a função conativa, chamada de função apelativa. É aquela que se centraliza no receptor, a mensagem está orientada ao destinatário e carrega traços de argumentação e persuasão, sendo muito utilizada pela publicidade. Chalhub (2002) enfatiza que mensagens que apresentam essa função possuem, no seu ato de configuração dos signos, características de função poética, que visam sensibilizar o público pela beleza da argumentação. No texto, "abismo", "vão ser mantidos vivos", "mais longa e documentada experiência humana", não exatamente por beleza, mas por serem palavras e expressões fortes, carregadas de sentidos, contribuem para despertar a curiosidade e seduzir o leitor para ler a matéria, comprar a revista.

Como dito anteriormente, não apenas uma função de linguagem está presente, mas várias funções dialogam numa mesma mensagem - uma delas determina o perfil principal, e as outras articulam e relacionam diferentes níveis de linguagem.

Chama à atenção a imagem escolhida para a capa ser justamente esse homem selecionado no meio de tantos outros, que recebeu inclusive 
um recorte destacando-o dos demais. Seus traços e sua expressão não nos levam, de início, a pensar que se trata de um trabalhador de uma mina, principalmente porque a capa representa o local pela palavra "abismo", que diz respeito mais a mistérios, profundezas, quedas, precipícios, decadências, situações difíceis.

Em "homens do abismo" podemos considerar que há também a função poética, levando em conta que se trata de uma frase metafórica. A metáfora diz respeito ao paradigma, ao eixo da seleção. De acordo com Jakobson, como lembra Chalhub (2002, p.37), "a função poética projeta o princípio de equivalência do eixo de seleção no eixo de combinação", ou seja, quando o eixo do sintagma projeta sobre o eixo do paradigma (combinação) há uma função poética.

A escolha e a combinação de uma palavra em um título de capa não são inocentes, vão além de sua mera definição. Se pensarmos no contexto político brasileiro do período em que a revista foi lançada, podemos associar a mensagem e a imagem a uma situação supostamente complexa e arriscada pela qual o Brasil passava.

\section{Padrões de manipulação}

Na imagem de capa (Figura 1), o trabalhador com chapéu vermelho pode nos remeter aos partidários do PT ou aos integrantes do MST, que em fotografias publicadas anteriormente pela revista aparecem com características parecidas. Algumas das informações semelhantes contidas nessas imagens são: barbas vastas, expressão do olhar, cores e tonalidades de roupas e acessórios, além da própria capa.

A imagem escolhida para ilustrar o ocorrido na mina não mostra a totalidade do acontecimento, mas, apenas um elemento para se referir ao todo. A escolha desse elemento, e eventual descarte de outros, carrega uma intencionalidade: é sobre o que Abramo (2003) trata quando fala da distorção da realidade e criação de outra, artificial. Os meios de comunicação têm o poder de selecionar o que pode ser notícia ou não e 
os critérios utilizados para essas escolhas tem a ver com "o projeto do órgão de imprensa, que são transmitidos, impostos ou adotados pelos jornalistas desse órgão". (ABRAMO, 2003, p.28).

Segundo a classificação de Perseu Abramo, um dos padrões de manipulação da imprensa que encontramos na análise da revista é o padrão de fragmentação.

A fragmentação da realidade em aspectos particularizados, a eliminação de uns e a manutenção de outros e a descontextualização dos que permanecem são essenciais, assim, à distorção da realidade e à criação artificial de uma outra realidade. (ABRAMO, 2003, p.28).

Dentre inúmeras imagens que poderiam ser utilizadas para representar o acidente e a própria mina, a escolha foi de um recorte de uma pessoa que não carrega um significado simbólico de um "personagem principal". Logo, podemos supor quais sejam as intencionalidades da revista.

Outro padrão que se encontra na capa é o padrão de inversão da forma pelo conteúdo no qual a explicação sobre o fato - e o fato em si - é ofuscada pela espetacularização da realidade. No caso, a manchete da capa diz que os trinta e três mineiros "vão ser mantidos vivos por quatro meses na mais longa e documentada experiência humana de isolamento coletivo subterrâneo". A questão do desabamento fica em segundo plano, e o que ganha destaque são as pesquisas e experiências em cima dessas pessoas, como se fossem cobaias de laboratório.

Não existe um caso de confinamento tão longo, em suma situação tão dramática, como a dos mineiros de San José. Segundo muitos psicólogos, ainda que tudo corra bem no resgate, é provável que eles saiam do episódio com problemas psicológicos severos, como transtorno obsessivo-compulsivo, crises de pânico, catatonia e mesmo esquizofrenia. Caso isso aconteça, pelo menos a ciência terá aprendido algo com seu sofrimento. (SALVADOR, 2010, p.141). 
De acordo com esses padrões de manipulação o leitor é induzido a ver algo, a realidade, como lhe é mostrada, e não como ela é de fato. Chegamos então ao padrão de indução, que é característica da grande imprensa da atualidade. A cada pequena manipulação, a população é levada a continuar enxergando a realidade distorcida e, portanto, estando nela inserida, não questiona, não reflete.

Atentamos, também, ao fato da imagem ser vista sempre dentro de um determinado contexto, que acompanha sua decodificação. Há vários elementos comunicativos que a constituem, como títulos, legendas e o próprio texto, que conforme utilizados podem manipular ou não a informação, de acordo com a intencionalidade de cada órgão de comunicação.

\section{Considerações finais}

Foi apresentada a imagem da capa de umas das mais conhecidas revistas do país, a Veja, e analisadas as mensagens transmitidas tanto por meio da fotografia como dos textos nela inseridos e seu poder de alcance. "É a conformidade ou não conformidade entre o tipo de relação imagem/ texto e a expectativa do espectador que confere à obra um caráter de verdade ou de mentira." (JOLY, 2006, p.117). Fica evidente que a grande mídia e as empresas de comunicação possuem poder de influência sobre a construção do pensamento de seu público. Cada escolha na forma de transmissão de informações não é isenta de intenção, sejam as linguagens quais forem-verbais ou imagéticas.

Essas informações, quando fragmentadas, invertidas, ocultas e combinadas com outros elementos próprios de cada linguagem, criam e recriam imagens há muito divulgadas e difundidas, que de certa maneira já fazem parte da memória coletiva, do imaginário dos leitores. Muitas vezes não instigam e não provocam o olhar do público, mantendo-o condicionado, conduzindo e induzindo seus pensamentos de acordo com as intenções de quem produz as informações e, principalmente, de quem as publica. 


\section{Referências}

ABRAMO, Perseu. Padrões de manipulação da grande imprensa.

São Paulo: Fundação Perseu Abramo, 2003.

AYOUB, Ayoub Hanna. Mídia e movimentos sociais: a satanização do MST na Folha de S. Paulo. 2006. Dissertação (Mestrado em Ciências Sociais) - Universidade Estadual de Londrina, Londrina.

BONI, Paulo César. Fotografia e mídia: da construção da imagem à veiculação de ideologias. Formas e Linguagens, Ijuí, ano 4, n.9, p.73-89, jan./jun. 2005.

CHALHUB, Samira. Funções da linguagem. 11.ed. São Paulo: Ática, 2002.

JOLY, Martine. Introdução à análise da imagem. 10.ed. Campinas: Papirus, 2006.

KUCINSKI, Bernardo. A síndrome da antena parabólica: ética no jornalismo brasileiro. São Paulo: Fundação Perseu Abramo, 1998.

ORLANDI, Eni Puccinelli. As formas do silêncio. 4.ed. Campinas: Unicamp, 1997.

SALVADOR, Alexandre. A vida no fundo do posso. Veja, São Paulo, ano 43, n.34, p.134-141, set. 2010. Disponível em: $<$ http:// veja.abril.com.br/acervodigital/home.aspx>. Acesso em: 17 maio 2011.

SANTAELLA, Lúcia. O que é semiótica. 12.ed. São Paulo: Brasiliense, 1984. 